\title{
EUFORIA OTONOMI DAERAH DALAM BINGKAI POLITIK HUKUM PASCA REFORMASI DI INDONESIA
}

\author{
Jamaludin \\ Dosen: IAIT Kediri
}

\begin{abstract}
A wave of regional autonomy in Indonesia, which led to the enactment of Law Number 23 of 2004 concerning Local Government and Government Regulation Number 78 of 2007 actually, in principle, as a correction of the weaknesses of Law Number 22 of 1999 and Government Regulation No. 129 of 2000 by tightening the requirements regional expansion. But in its implementation, the Government Regulation Number. 78 of 2007 is not effective, due to the politicization of interest. Legal product is basically a political product, but many aspects people interest must necessarily remain the main spirit of the laws themselves. For the essential decentralization and regional autonomy are to the welfare of the community, shortening the span of control, and improve public services
\end{abstract}

Keywords: Autonomous Region, Politics, Law, Reform

\begin{abstract}
ABSTRAK
Gelombang otonomi daerah di Indonesia, yang bermuara pada lahirnya UndangUndang Nomor 23 tahun 2004 tentang Pemerintah Daerah dan Peraturan Pemerintah Nomor 78 tahun 2007 sesungguhnya pada prinsipnya sebagai koreksi kelemahan Undang-Undang Nomor 22 tahun 1999 dan Peraturan Pemerintah Nomor 129 tahun 2000 dengan memperketat syarat pemekaran daerah. Namun dalam pelaksanaanya, Peraturan Pemerintah Nomor 78 tahun 2007 tersebut tidak berjalan efektif, karena terjadi politisasi kepentingan. Produk hukum pada dasarnya merupakan produk politik, namun aspek kepentingan rakyak banyak tentu harus tetap menjadi spirit utama dari produk hukum itu sendiri. Karena pada essensinya desentralisasi dan otonomi daerah adalah untuk mensejahterakan masyarakat, memperpendek rentang kendali, dan memperbaiki pelayanan publik
\end{abstract}

Kata Kunci: Otonomi Daerah, Politik Hukum, Reformasi 


\section{A. PENDAHULUAN}

\section{Latar Belakang Masalah}

Politik dan hukum merupakan dua kutub ilmu sosial yang menonjol dalam konteks keilmuan masa kini. Hal tersebut dikarenakan perkembangan politik dan hukum saat ini melaju sangat pesat meninggalkan kompetitor lainya, sehingga aplikasi politik dan hukum harus mengacu kepada konstitusi yang berlaku di negara Republik Indonesia. Sebagian orang beranggapan bahwa hukum dan politik bersifat kontradiktif, ibarat air dan minyak selamanya tidak dapat bersatu, namun disisi lain ada benang merah yang menyatukan kedua kutub besar tersebut. Dalam konteks politik dikenal politik hukum sedangkan dalam konteks hukum dikenal hukum tata negara.

Perubahan konstitusi sejak amandemen UUD 1945 pertama hingga yang keempat telah menambahkan salah satu point penting dalam kehidupan berbangsa dan bernegara. Pasal 1 ayat (3) UUD 1945 bahwa negara Indonesia adalah negara hukum. Semangat reformasi penegakan hukum yang ada dalam jiwa legislatif menjadi pemicu utama keberhasilan untuk mencantumkan asas hukum secara empiris dalam konstitusi kita, akan tetapi semangat itu lambat laun mulai pudar.

Produk hukum yang selama ini terbentuk melalui mekanisme politik, sedikit demi sedikit justru mulai bergeser jauh dari asas kerakyatan yang selama ini dijunjung tinggi oleh konstitusi. Kondisi ini dilatarbelakangi oleh konsepsi politik-hukum yang samgat kental. Ketika hukum sudah terpolitisasi, maka secara tidak langsung produk hukum yang ada tidak akan bersifat adil, karena memiliki kecenderungan untuk menguntungkan kelompok tertentu. ${ }^{1}$

\section{Rumusan Masalah}

a. Mengapa Peraturan Pemerintah Nomor 78 Tahun 2007 tersebut tidak berjalan efektif.

${ }^{1}$ A. Gelora Mahardika, Membangun Moralitas Politik Hukum: Catatan Harian Seorang Birokrat, (Surabaya: Jenggala Pustaka Utama, 2014), hlm. 2 
b. Apakah aspek kepentingan rakyat banyak harus tetap menjadi spirit utama dari produk hukum.

\section{Tujuan Penelitian}

a. Untuk mengkaji secara mendalam Peraturan Pemerintah Nomor 78 Tahun 2007 tersebut tidak berjalan efektif.

b. Untuk mengkaji secara mendalam aspek kepentingan rakyat banyak harus tetap menjadi spirit utama dari produk hukum.

\section{B. PEMBAHASAN}

\section{Pengertian Otonomi dan Desentralisasi}

Istilah otonomi (autonomy) secara etimologi berasal dari kata Yunani "autos" yang berarti sendiri dan "nomous" yang berarti hukum atau peraturan. Menurut Encyclopediaa of Social Science, bahwa otonomi dalam pengertian orisinil adalah the legal self sufficiency of social body ist actual independence. Dengan demikian ada dua ciri hakekat dari otonomi, yaitu "legal self sufficiery" dan "actual independce".

Sedangkan istilah desentralisasi berasal dari bahasa Latin "de" yang berarti lepas, dan "centrum" artinya pusat. "Desentralisasi" merupakan lawan kata dari "Sentralisasi" sebab kata "de" dimaksudkan untuk menolak kata sebelumnya, sehingga desentralisasi bermakna melepas atau menjauh dari pusat. Desentralisasi tidak putus sama sekali dengan (pemerintah) pusat tetapi hanya menjauh dari (pemerintah) puat. $^{2}$

Batasan tentang desentralisasi merujuk pada pemindahan kekuasaan dari pemerintah pusat, baik melalui dekonsentrasi (delegasi) pada pejabat wilayah maupun melalui devolusi pada badan-badan otonomi daerah. ${ }^{3}$ Asas desentralisasi tumbuh dan berkembang seiring dengan tututan dan kebutuhan negara demokrasi. Asas desentralisasi baru banyak

\footnotetext{
${ }^{2}$ R.D.H. Koesoemahatmadaja, Pengantar ke Sistem Pemerintahan Daerah di Indonesia, (Bandung: Bina Cipta, 1979), hlm. 14

3 Hanif Nurcholis, Teori dan Praktek Pemerintahan dan Otonomi Daerah, (Jakarta: Grasindo, 2005), hlm. 11
} 
diperdebatkan khususnya di negara-negara yang sedang berkembang pada tahun 1950-an.

Pada periode tersebut dapat dikatakan sebagai "gelombang" pertama konsep desentralisasi telah mendapat perhatian khusus dan telah diartikulasikan sebagai konsep yang paling relevan untuk memperkuat dan memberdayakan penyelenggaraan pemerintah lokal, sedangkan gelombang kedua gerakan desentralisasi pada akhir tahun 1970-an. ${ }^{4}$

Pemaknaan asas desentralisasi menjadi perdebatan di kalangan pakar dalam mengkaji dan melihat penerapan asas ini dalam pelaksanaan desentralisasi pemerintah daerah. Perdebatan yang muncul diakibatkan oleh cara pandang dalam mengartikulasikan sisi mana desentralisasi diposisikan dalam pelaksanaan pemerintah daerah.

Berdasarkan perdebatan pemaknaan asas desentralisasi masingmasing pakar tersebut dapat diklasifikasikan dalam beberapa pandangan, diantaranya :

a. Desentralisasi sebagai penyerahan kewenangan dan kekuasaan .

b. Desentralisasi sebagai pelimpahan kekuasaan dan wewenang.

c. Desentralisasi sebagai pembagian, penyebaran, pemencaran, dan pemberian kekuasaan dan wewenang.

d. Desentralisasi sebagai sarana dalam pembagian dan pembentukan daerah pemerintahan.

\section{Euforia Otonomi Daerah}

Desentralisasi dan Otonomi Daerah yang berlangsung sejak tanggal 1 Januari 2001 adalah sebuah peristiwa yang menimbulkan perubahan mendasar pada hubungan antar Pemerintah Pusat dan Daerah. Hubungan yang semula sentralistik menjadi desentralistik yang di tandai dengan pemberian otonomi yang luas dan nyata kepada daerah.

Sebagai konsekwensi logis dari perubahan tersebut, maka lahirnya kebijakan pemerintah yang berpengaruh terhadap kedudukan, tugas dan

\footnotetext{
${ }^{4}$ Syarif Hidayat dan Bhenyamin Hoessein, Desentralisasi dan Otonomi Daerah, dalam Paradigma Baru Otonomi Daerah, (Jakarta: P2p-LIPI, 2001), hlm. 22.
} 
fungsi lembaga pemerintah di pusat dan di daerah. Kebijakan otonomi daerah pada hakikatnya dipandang sebagai upaya untuk memberikan kesempatan yang luas bagi daerah untuk mengembangkan struktur pemerintahan yang sesuai dengan kebutuhan daerah dan responsif terhadap kepentingan masyarakat luas untuk mengembangkan sistem manajemen pemerintahan daerah yang baik, efektif, efisiensi, bersih, transparan dan akuntabilitas (Clean and Good Governance).

Dalam konteks sistem ketatanegaraan Indonesia, euforuia reformasi yang ditandai dengan gelombang otonomi daerah secara besar-besaran. Lahirnya UU Pemerintahan daerah pada kondisi tersebut merupakan salah satu upaya pemerintah "mendinginkan" euforia reformasi disatu sisi dan di lain pihak untuk menjaga keutuhan Negara Kesatuan Republik Indonesia (NKRI), maka tidak salah kiranya apabila "nada" UU Nomor 22 Tahun 1999 tentang Pemerintahan Daerah memberikan kebebasan nyata bagi daerah untuk menyelenggarakan pemerintahanya sendiri (otonom) demi kesejahteraan dan kemakmuran daerah. Prinsip kebebasan, demokrasi, dan partisipasi publik juga sangat kuat dan menonjol dalam produk hukum tersebut. $^{5}$

Dalam konteks politik pasca reformasi, desentralisasi dimaknai sebagai kebebasan daerah untuk melalukan pemekaran daerah atau pembentukan daerah otonom baru, baik provinsi, kab/kota, kecamatan \& desa/kelurahan.

Dalam konteks negara hukum modern (welfare staat), setiap kebijakan pemerintah, termasuk pemekaran daerah harus berimplikasi pada kepentingan umum, yaitu memberikan kontribusi positif bagi peningkatan kualitas pelayanan publik yang merata dan terjangkau bagi semua kelompok masyarakat dan mencegah ketimpangan sosial antar daerah. ${ }^{6}$

${ }^{5}$ Tim Percik, Proses dan Implikasi Sosial-Politik Pemekaran: Studi Kasus di Sambas dan Buton, Yayasan Percik, (Salatiga: Summary Paper-pdf, 2007), hlm. 5

6 Rico Afrido, Pemekaran Daerah, DPR mengesahkan Kab. Musi Rawas Utara, www.SINDO new.com, \& www.Okezone.new.com. 
Ketentuan tersebut di atas sesungguhnya secara yuridis telah termuat dalam UU Nomor 22 Tahun 1999, (yang kemudian direvisi melalui UU 32 Tahun 2004) yang secara teknis diatur dalam PP Nomor 129 Tahun 2000 (yang kemudian direvisi melalui PP Nomor 78 Tahun 2007) sebagai acuan untuk mewujudkan tujuan pemekaran daerah, yaitu meningkatnya kesejahteraan masyarakat, pelayanan prima yang lebih baik, peningkatan kehidupan demokratis, pertumbuhnan ekonomi lebih cepat, meningkatkan keamanan dan ketertiban, relasi dan interaksi sosial yang harmonis antar daerah dan memperpendek rentang kendali pemerintahan. ${ }^{7}$

Dibalik tujuan ideal tersebut dalam praktiknya ternyata terselip kepentingan politik dan kekuasaan yang justru menafikan tujuan pemekaran daerah secara keseluruhan, sehingga dapat dipahami bahwa pemekaran daerah hanya merupakan rekayasa elit politik, baik lokal maupun nasional, dengan berbagai kepentingan yang diusungnya yang tidak memperhatikan aspek viability (rasionalitas dan urgensitas), maupun feasibility (kelayakan). ${ }^{8}$

Secara teoritis dan praktis, terdapat lima jenis otonomi (sistem rumah tangga daerah, yaitu :

a. Otonomi organik (rumah tangga organik), otonomi bentuk ini pada dasarnya menentukan bahwa urusan-urusan yang menyangkut kepentingan daerah diibaratkan sebagai organorgan kehidupan yang merupakan suatu sistem yang menentukan mati hidupnya manusia.

b. Otonomi formal (rumah tangga formal) otonomi bentuk ini adalah apa saja yang menjadi urusan otonomi tidak dibatasi secara positif. Otonomi seperti ini merupakan hasil dari pemberian otonomi berdasarkan "teori sisia" diurus oleh pusat, sedangkan pemerintah pusat lebih dahulu menetapkan urusan-

\footnotetext{
${ }^{7}$ Penjelasan Undang-undang Nomor 22 Tahun 1999 tentang Pemerintahan Daerah

8 Cornalis Lay dan Purwo Santoso, Perjuangan Menuju Puncak, Kajian Akademik Pembentukan Pancak Jaya Papua, Kerjasama dengan PLOD UGM dan Pemerintah Daerah Papua, 2006.
} 
urusan yang dipandang lebih layak diurus oleh pusat, sedangkan sisanya diserahkan kepada pemerintah daerah.

c. Otonomi materiil (rumah tangga materiil), dalam otonomi bentuk ini kewenangan daerah dibatasi secara positif, yaitu dengan menyebut secara limitatif dan terinci atau secara tegas apa yang berhak diatur dan diurusnya. Kemudian untuk penyelenggaraan rumah tangga itu obyek tugas yang dikuasakan wewenang satu demi satu (terinci secara enumeratif).

d. Otonomi riil (rumah tangga riil) otonomi bentuk ini merupakan gabungan antara otonomi formal dan otonomi materiil. Dalam undang-undang pembentukan otonomi, pemerintah daerah diberikan wewenang pangkal dan wewenang lainya secara bertahab dan tidak boleh bertentangan dengan peraturan perundang-udangan yang lebih tinggi.

e. Otonomi nyata, bertanggung jawab dan dinamis.

1) Nyata, artinya pemberian urusan pemerintahan dibidang tertentu kepada pemerintah daerah yang harus disesuaikan dengan faktor-faktor tertentu yang hidup dan berkembang secara obyektif di daerah tersebut. Hal ini wajar dan sesuai dengan karakter daerah masing-masing yang memiliki perbedaan geografis, kondisi geologis, budaya, adatistiadat dan potensi lainya yang dimiliki daerah.

2) Bertanggung jawab, artinya pemberian otonomi kepada pemerintah daerah senantiasa diupayakan supaya selaras dan sejalan dengan tujuan pembangunan diseluruh pelosok negara Indonesia.

3) Dinamis, artinya otonomi ini menghendaki agar pelaksana otonomi senantiasa menjadi sarana untuk memberikan dorongan yang lebih baik dan maju atas seluruh kegiataan 
pemerintahan dalam rangka memberikan pelayanan yang semakin meingkat mutunya.

\section{Demokrasi sebagai Pijakan Bernegara}

Dalam perkembangan negara modern, demokrasi menjadi pilihan utama di banyak negara sebagai konsep dalam menjalankan tatanan pemerintahan. Demokrasi dianggap sangat dekat dengan konsep kedaulatan rakyat yang menekankan bahwa kedaulatan berada di tangan rakyat, sehingga sinergisitas konsep ini adalah bagaimana membentuk suatu pemerintahan yang didasarkan atas kehendak bersama dan untuk menjalankan kepentingan dan hak-hak rakyat banyak (maslahat alammah). ${ }^{9}$

Istilah demokrasi berasal dari dua kata Yunani, yaitu Demos yang artinya rakyat dan Cratos yang artinya pemerintah. Sehingga demokrasi adalah pemerintan dari rakyat, oleh rakyat dan untuk rakyat. ${ }^{10}$ Secara harfiah kata demokrasi dapat diartikan sebagai rakyat memerintah atau kekuasaan yang ada pada rakyat seluruhnya. Artinya demokrasi dapat dipahami sebagai bentuk pemerintahan atau kekuasaan yang bersumber kekuasaan tingginya adalah rakyat. ${ }^{11}$

Sedangkan urgensi demokrasi dalam negara hukum menurut Robert Dahl terdiri enam elemen penting, yaitu :

a. Adanya pejabat yang dipilih.

b. Pemilu yang bebas, adil dan berkala

c. Kebebasan berpendapat.

d. Akses informasi alternative.

e. Atonomisasi asosiasional.

${ }^{9}$ Syahda Guruh Langkah Samudra, Menimbang Otonomi VS Federal: Mengembangkan Wacana Federalisme dan Otonomi Nenuju Masyarakat Madani Indonesia, Cet. I, Ibandung: PT Remaja Rosdakarya, 2000), hlm. 131-132.

${ }^{10}$ BN Marbun, Kamus Politik, Edisi Baru, (Jakarta: Pustaka Sinar Harapan, 2007), hlm. 115

${ }^{11}$ Murtir Jeddawi, Pro-Kontra Pemekaran Daerah, (Yogyakarta: Kreasi Total Media, 2009), hlm. 4 
Hak kewarganegaraan yang inklusif (sebagai sikap tanggap pemerintah secara terus memerus terhadap preferensi atau kepentingan warga negara).12 Dengan kata lain negara hukum harus ditopang dengan sisten demokrasi yang baik, hubungan antara keduanya tidak dapat dipisahkan. Demokrasi tanpa pengaturan hukum akan kehilangan bentuk dan arah, sedangkan hukum tanpa demokrasi akan kehilangan makna. ${ }^{13}$

Jimly Asshiddiqie menegaskan bahwa teori tentang negara hukum (rule of law and rechtsstaat) pada hahekatnya tidak dapat dipisahkan dari teori tentang demokrasi, keduanya harus dilihat sebagai dua sisi mata uang yang sama. ${ }^{14}$ Sedangkan negara hukum demokrasi (democratische rechtsstaat) itu adalah merupakan konstitusi dalam arti ideal (ideal bergriff der verfassung). ${ }^{15}$ Terdapat korelasi yang jelas antara negara hukum yang bertumpu pada konstitusi dengan kedaulatan rakyat yang dijalankan melalui sistem demokrasi. Dalam korelasi ini partisipasi rakyat merupakan faktor utama dan penting yang essensial. ${ }^{16}$

Larry Diamond menegaskan bahwa terdapat lima alasan, mengapa sebuah pemerintahan mengimplementasikan demokrasi, termasuk pemerintahan lokal sekalipun, yaitu ;

a. Demokrasi menyediakan ruang bagi partisipasi secara luas dan otonom bagi setiap individu. Satu aturan dasar dari demokrasi adalah kebebasan individu untuk terlibat langsung dalam kehidupan berbangsa daan bernegara. Partisipasi publik yang egaliter, otonom, dan efektif dalam

${ }^{12}$ Murtir Jeddawi, Pro-Kontra Pemekaran Daerah, (Yogyakarta: Kreasi Total Media, 2009), hlm. 4

${ }^{13}$ Ridwan HR., Hukum Administrasi Negara, Cet. II, (Yogyakarta: UII Press, 2003), hlm. 6

${ }^{14}$ Jimly Asshiddiqie, Pokok-pokok Hukum Tata Negara Indonesia Pasca Reformasi, (Penerbit BIP, 2007), hlm. 300

${ }^{15}$ Jjokosutono, Hukum Tata Negara, Himpunan Kuliah Harun ar-Rasyid, (Jakarta: Ghalia Indonesia, 1982), hlm. 199-200.

${ }^{16}$ Irine H. Gayatri, Demokrasi Lokal (di Desa) Quo Vadis, dalam http:/www.intereksi.org, di akses tanggal 10 Januari 2016. 
mendorong pembangunan politik ke arah yang lebih baik, beradab dan berkualitas.

b. Kontrol atau pengawasan politik. Karena partisipasi politik juga bersinggungan dengan pengawasan. Pengawasan politik akan sangat baik apabila dilaksanakan bukan hanya oleh orang-orang yang berada dalam struktur kekuasaan, tetapi juga mereka yang berada di luar struktur kekuasaan (chack and balances) dalam pengertian yang lebih luas.

c. Demokrasi menyediakan ruang bagi sirkulasi elite yang kompetitif dan berkala (sekuensial).

d. Tersedianya mekanisme pengelolaan dan penyelesaian konflik yang efektif. Kompetisi taanpa aturan akan menimbulkan konflik yang dibarengi dengan kekerasan, oleh karena itu demokrasi harus mampu menyediakan mekanisme teknis dan praktis sebagai upaya pengelolaan dan penyelesaian konflik secara akomodatif konsensual.

e. Demokrasi membantu menjaga kepentingan dan hak milik warganya. Kebebasan bertanggung jawab merupakan kata kunci dalam membangun demokrasi.

Salah satu perwujudan demokratisasi di Indonesia adalah adanya konsep desentralisasi pemerintahan sejak era reformasi sebagai antitesa dari konsep sentralisasi yang diterapkan oleh rezim orde baru. Implikasinya adalah terjadinya pergeseran lokus kekuasaan dari pusat ke daerah. Dengan semangat desentralisasi, daerah semakin memiliki kewenangan berotonomi yang semakin luas. ${ }^{17}$

Desentralisasi secara umum dapat dikategorikan ke dalam dua perspektif utama, yaitu perspektif desentralisasi politik dan desentralisasi adminstrasi. Perspektif desentralisasi politik menerjemahkan disentralisasi sebagai devolusi kekuasaan dari pemerintah pusat kepada pemerintah daerah, sedangkan perspektif

\footnotetext{
${ }^{17}$ Sudi Fahmi, Hukum Otonomi Daerah, hlm. 21
} 
desentralisasi administrasi diartikan sebagai pendelegasian wewenang administrasi dari pemerintah pusat kepada pemerintah daerah. ${ }^{18}$

\section{Desentralisasi dan Otonomi Daerah}

Desentralisasi merupakan suatu istilah yang dapat dihubungkan dengan prinsip negara kesatuan, yaitu negara yang tersusun dari pada beberapa negara, dengan demikian negara kesatuan hanya ada satu pemerintahan, yaitu pemerintah pusat yang mempunyai kekuasaan dan wewenang tertinggi dalam segala lapangan pemerintahan.

Dianutnya sistem desentralisasi kepada negara kesatuan, karena desentralisasi memiliki keuntungan-keuntungan sebagai berikut :

a. Mengurangi penumpukan kewengan dan pekerjaan di pusat,

b. Dalam menghadapi masalah-masalah yang sangat mendesak yang membutuhkan tindakan cepat, maka daerah tidak perlu menunggu instruksi dari pusat,

c. Memutus mata rantai birokrasi yang terlalu birokratis menuju pelayanan prima dan mengurangi birokrasi dalam arti buruk,

d. Dapat diadakan pembedaan \& pengkhususan yaang berguna bagi kepentingan tertentu,

e. Daerah dapat dijadikan laboratorium pemerintahan,

f. Mengurangi kemungkinan perilaku dan sikap kesewenangwenangan pemerintah pusat,

g. Secara psikologis dapat memberikan kepuasan langsung kepada masyarakat daerah.

${ }^{18}$ Syarif Hidayat, Refleksi Realitas Otonomi Daerah dan Tantangan ke Depan, (Jakarta: Pustaka Quantum, 2000), hlm. 29 


\section{PENUTUP}

\section{Kesimpulan}

a. Gelombang otonomi daerah di Indonesia, yang bermuara pada lahirnya Undang-Undang Nomor 23 Tahun 2004 tentang Pemerintah Daerah dan Peraturan Pemerintah Nomor 78 Tahun 2007 sesungguhnya pada prinsipnya sebagai koreksi kelemahan Undang-Undang Nomor 22 tahun 1999 dan Peraturan Pemerintah Nomor 129 Tahun 2000 dengan memperketat syarat-syarat pemekaran daerah. Namun dalam pelaksanaanya, Peraturan Pemerintah Nomor 78 Tahun 2007 tersebut tidak berjalan efektif, karena terjadi politisasi kepentingan.

b. Produk hukum pada dasarnya merupakan produk politik, namun aspek kepentingan rakyak banyak tentu harus tetap menjadi spirit utama dari produk hukum itu sendiri. Karena pada essensinya desentralisasi dan otonomi daerah adalah untuk mensejahterakan masyarakat, memperpendek rentang kendali, dan memperbaiki pelayanan publik. 


\section{DAFTAR PUSTAKA}

Cornalis Lay \& Purwo Santoso, Perjuangan Menuju Puncak; Kajian Akademik Pembentukan Pancak Jaya Papua, Kerjasama dengan PLOD UGM dan Pemerintah Daerah Papua, 2006.

Djokosutono, Hukum Tata Negara, Himpunan Kuliah Harun ar-Rasyid, Jakarta: Ghalia Indonesia, 1982.

Gelora Mahardika, A., Membangun Moralitas Politik Hukum: Catatan Harian Seorang Birokrat, Surabaya: Jenggala Pustaka Utama, 2014.

Hanif Nurcholis, Teori dan Praktek Pemerintahan dan Otonomi Daerah, Jakarta: Grasindo, 2005.

Hestu Cipto Handoyo, B., Hukum Tata Negara, Kewarganegaraan dan Hak Asasi Manusia, Yogyakarta: Andi Offset, 2000. Sudi Fahmi, Hukum Otonomi Daerah, Yogyakarta: Kreasi Total Media, 2010.

Irine H. Gayatri, Demokrasi Lokal (di Desa) Quo Vadis, dalam http:/www.intereksi.org.

Jimly Asshiddiqie, Pokok-pokok Hukum Tata Negara Indonesia Pasca Reformasi, Penerbit BIP, 2007.

Marbun, B.N., Kamus Politik, Edisi Baru, Jakarta: Pustaka Sinar Harapan, 2007.

Murtir Jeddawi, Pro-Kontra Pemekaran Daerah, Yogyakarta: Kreasi Total Media, 2009.

Penjelasan Undang-undang No. 22 Tahun 1999 tentang Pemerintahah Daerah.

R.D.H. Koesoemahatmadaja, Pengantar ke Sistem Pemerintahan Daerah di Indonesia, Bandung: Bina Cipta, 1979.

Rico Afrido, Pemekaran Daerah, DPR mengesahkan Kab. Musi Rawas Utara, www.SINDO new.com, \& www.Okezone.new.com.

Ridwan HR., Hukum Administrasi Negara, Cet. II, Yogyakarta: UII Press, 2003.

Syahda Guruh Langkah Samudra, Menimbang Otonomi VS Federal: Mengembangkan Wacana Federalisme dan Otonomi Nenuju Masyarakat Madani Indonesia, Cet. I, Ibandung: PT Remaja Rosdakarya, 2000.

Syarif Hidayat dan Bhenyamin Hoessein, Desentralisasi dan Otonomi Daerah, dalam Paradigma Baru Otonomi Daerah, Jakarta: P2p-LIPI, 2001.

Refleksi Realitas Otonomi Daerah dan Tantangan ke Depan, Jakarta: Pustaka Quantum, 2000.

Tim Percik, Proses dan Implikasi Sosial-Politik Pemekaran: Studi Kasus di Sambas dan Buton, Yayasan Percik, Salatiga: Summary Paper-pdf, 2007. 